
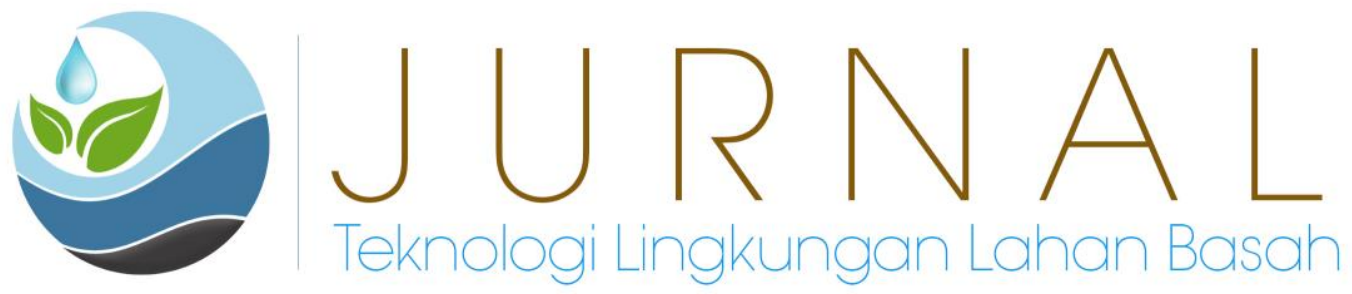

\title{
Kajian Kualitas Air Danau Hanjalutung untuk Kegiatan Perikanan di Kelurahan Petuk Katimpun, Kota Palangka Raya, Kalimantan Tengah
}

\author{
Rosana Elvince $^{1^{*}}$ dan Kembarawati ${ }^{1}$ \\ ${ }^{1}$ Program Studi Manajemen Sumberdaya Perairan, Jurusan Perikanan, \\ Fakultas Pertanian, Universitas Palangka Raya \\ *E-mail : rosana@fish.upr.ac.id
}

\begin{abstract}
This study aimed to determine water quality of Lake Hanjalutung based on physical and chemical parameters compared to water quality standards (PP No. 82/2001 class II and III). This research was conducted at three sampling points in Hanjalutung Lake, Petuk Katimpun Village, Palangka Raya City, Central Kalimantan to measure water quality of the lake. The results showed that the water quality physical and chemical parameters such as pH, Nitrate, Phosphate, BOD, COD, TDS, TSS are still below the water quality standards of class II and III with Government Regulation No. 82 of 2001, however some parameters such as Temperature, Turbidity, Depth and DO still meet the quality standards of class II and III.
\end{abstract}

Keywords: Water Quality; Water Quality Standards; Hanjalutung Lake

\begin{abstract}
Abstrak
Penelitian ini bertujuan untuk menganalisis kualitas air Danau Hanjalutung yang berada di Kelurahan Petuk Katimpun, Kota Palangka Raya, Kalimantan Tengah dan membandingkan dengan Standar Baku Mutu Air yang ditetapkan oleh Pemerintah yaitu PP No. 82 Tahun 2001 terutama standard kualitas air untuk Kelas II dan Kelas III. Hasil penelitian menunjukkan bahwa kualitas air (parameter fisika dan kimia) seperti pH, Nitrat, Pospat, BOD, COD, TDS, dan TSS masih dibawah standar baku mutu yang ditetapkan oleh Pemerintah yaitu untuk Kelas II dan Kelas III, sedangkan suhu, kecerahan, kedalaman dan DO masih memenuhi satandar baku mutu untuk Kelas II dan Kelas III.
\end{abstract}

Kata Kunci: Kualitas Air; Standar Baku Mutu; Danau Hanjalutung 


\section{PENDAHULUAN}

Provinsi Kalimantan Tengah merupakan salah satu provinsi di Indonesia, yang memiliki luasan wilayah $157,983 \mathrm{~km}^{2}$ dengan wilayah perairan umum seluas 2,293,633 ha (BAPPEDA, 2016). Dengan luas perairan danau 132,800 ha yang terdiri dari 690 danau, sungai 323,500 ha yang terdiri dari 11 sungai besar, dan 1,811,500 ha rawa. Dari luas lahan rawa yang terdapat di Kalimantan Tengah, sekitar 1,8 juta ha merupakan lahan rawa yang digunakan untuk usaha perikanan (DKP, 2011).

Danau merupakan perairan umum yang sering dimanfaatkan untuk usaha perikanan oleh masyarakat Kalimantan Tengah dalam memenuhi kebutuhan hidupnya, seperti mata pencaharian dengan penangkapan dan budidaya ikan, serta pelestarian stok ikan. Salah satu danau di Kota Palangka Raya, Kalimantan Tengah yang sering digunakan dalam usaha perikanan oleh masyarakat sekitar adalah Danau Hanjaluntung yang terletak di wilayah administratif Kelurahan Petuk Katimpun, Kecamatan Jekan Raya, Kota Palangka Raya Provinsi Kalimantan Tengah.

Danau Hanjalutung merupakan danau oxbow yaitu danau di dataran banjir dari sungai-sungai besar yang terbentuk akibat aliran sungai yang terputus (sungai mati). Danau oxbow pada umumnya berukuran kecil namun memiliki produkivitas ikan yang tinggi. Produktivitas ikan yang tinggi di dataran banjir disebabkan oleh ketersediaan pakan alami terutama zooplankton. Danau Hanjalutung merupakan danau yang masih berhubungan dengan Sungai Rungan dengan sumber utama airnya berasal dari Sungai Rungan melalui satu inlet dari bagian utara (hulu) danau dan satu outlet di bagian selatan (hilir). Luas permukaan Danau Hanjalutung sekitar 11,7 hektar dengan kedalaman maksimum 8 meter. Luas limpasan banjir mencapai 7 hektar dengan tinggi limpasan banjir mencapai 2 meter diatas rata- rata tinggi permukaan air sejajar mulut basin danau (lake's bank) (Augusta, T. S., 2013)

Dalam upaya membantu menjaga kelestarian Danau Hanjalutung sebagai daerah konservasi, daerah penangkapan, dan budidaya maka perlu dilakukan analisis terhadap kualitas air terutama secara fisika dan kimia. Beberapa penelitian yang telah dilakukan di Danau Hanjalutung oleh beberapa peneliti diantaranya adalah Augusta, T.S (2013), Augusta, T.S dan Evi, S, U. (2014); Augusta, T.S (2015); Susila, N (2017); Akhdiana, I., dkk (2017) dan (Suraya, U., 2019).

\section{Tujuan Penelitian}

Tujuan penelitian ini adalah untuk mengetahui kualitas air Danau Hanjalutung yang memenuhi persyaratan terutama bagi kegiatan perikanan.

\section{METODE PENELITIAN}

\section{Waktu dan Tempat Penelitian}

Penelitian ini dilaksanakan di Danau Hanjaluntung Desa/Kelurahan Petuk Katimpun, Kecamatan Jekan Raya Kota Palangka Raya Provinsi Kalimantan Tengah. Pengambilan sampel air dilakukan sekali dalam seminggu dalam waktu 3 (tiga) minggu pada bulan Agustus 2019. 
Peta lokasi dan stasiun pengambilan sampel dapat dilihat pada Gambar 1a dan 1b. Gambar 1a adalah peta lokasi penelitian dan Gambar $\mathbf{1 b}$ adalah stasiun pengambilan sampel air. Pengambilan sampel air dilakukan pada 3 (tiga) stasiun. Stasiun 1 berada didekat inlet (LS 20 9' 2" BT $113^{\circ} 51^{\prime} 12^{\prime}$ ), Stasiun 2 berada di bagian tengah danau (LS $2^{\circ} 7^{\prime} 19^{\prime \prime}$ BT $113^{\circ} 52^{\prime} 1^{\prime \prime}$ ), Stasiun 3 berada sekitar outlet (LS 2 $7^{\prime} 26^{\prime \prime}$ BT $113^{\circ} 48^{\prime} 23^{\prime \prime}$ ).

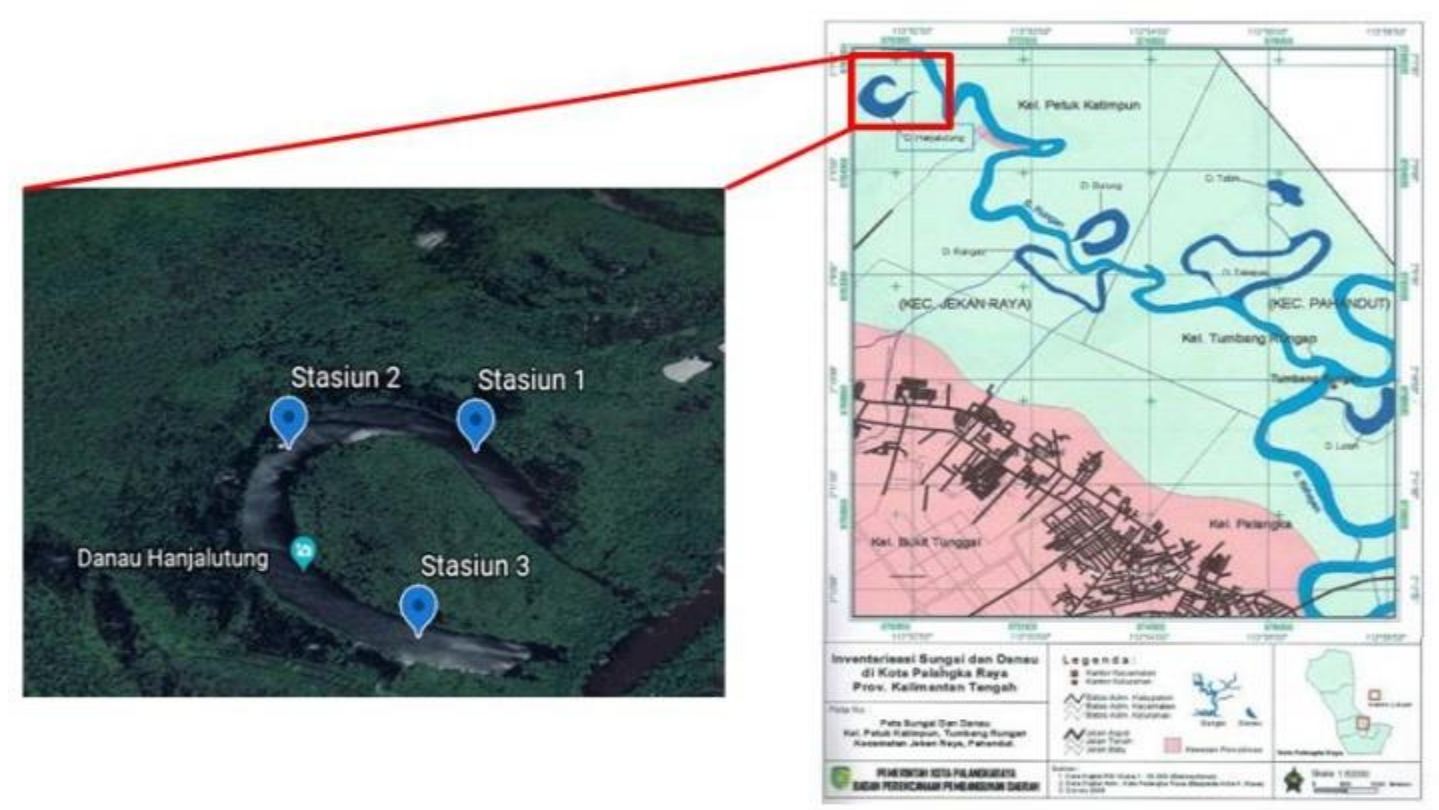

Gambar 1. (a) Peta Lokasi; (b) Stasiun Pengambilan Sampel Air

\section{Alat dan Bahan}

Adapun alat dan bahan yang digunakan dalam kegiatan penelitian disajikan dalam Tabel 1 dibawah ini:

Tabel 1. Alat dan Bahan yang Digunakan Dalam Penelitian

\begin{tabular}{|l|l|l|}
\hline No. & \multicolumn{1}{|c|}{ Alat dan Bahan } & \multicolumn{1}{c|}{ Kegunaan } \\
\hline 1. & Water checker & Untuk mengukur Suhu dan Oksigen Terlaur \\
\hline 2. & Secchi disc & Untuk mengukur kecerahan \\
\hline 3. & Batu duga & Untuk mengukur kedalaman \\
\hline 4. & TDS meter & Untuk mengukur TDS \\
\hline 5. & pH meter & Untuk mengukur pH \\
\hline 6. & Sampel air & Bahan yang akan dianalisi di laboratorium \\
\hline 7. & Kamera & Untuk mendokumentasikan kegiatan selama penelitian \\
\hline 8. & Alat tulis & $\begin{array}{l}\text { Untuk melakukan pencatatan data selama melakukan } \\
\text { penelitian }\end{array}$ \\
\hline
\end{tabular}




\section{Prosedur Pengambilan Sampel Air}

Pengambilan sampel air dilakukan sekali seminggu dalam waktu 3 (tiga) minggu. Sampel air tersebut dikirim ke Laboratorium BBTKLPP Banjarbaru, Kalimantan Selatan untuk mengetahui kandungan TSS (Total Suspended Solid), Pospat, Nitrat, COD (Chemical Oxygen Demand) dan BOD (Biochemical Oxygen Demand). Sedangkan pengukuran suhu, oksigen terlarut, kecerahan, TDS (Total Dissolved Suspended) dan $\mathrm{pH}$ dilakukan secara langsung pada saat pengambilan sampel air.

\section{Analisis Data}

Analisis data dilakukan secara tabulasi, grafik dan deskriptif, berdasarkan hasil analisis laboratorium kemudian dibandingkan dengan standar air baku sesuai dengan PP No. 82 Tahun 2001 tentang pengelolaan kualitas air dan pengendalian pencemaran air, dengan pembagian kelas I-IV yaitu:

1. Kelas I yaitu air yang peruntukannya dapat digunakan untuk air baku air minum dan atau peruntukan lain yang mempersyaratkan mutu air yang sama dengan kegunaan tersebut

2. Kelas II yaitu air yang peruntukannya dapat digunakan untuk sarana dan prasarana rekreasi air, pembudidayaan ikan air tawar, peternakan dan air untuk mengairi tanaman

3. Kelas III yaitu adalah air yang peruntukannya dapat digunakan untuk pembudidayaan ikan air tawar, peternakan, air untuk mengairi tanaman dan atau peruntukan lain yang mempersyaratkan mutu air yang sama dengan kegunaan tersebut

4. Kelas IV merupakan air yang peruntukannya dapat digunakan untuk mengairi tanaman.

\section{HASIL DAN PEMBAHASAN}

\subsection{Kualitas Air}

Rata-rata kualitas air Danau Hanjalutung berdasarkan parameter fisika (suhu, kecerahan, kedalaman, TDS dan TSS) dan kimia (pH, DO, Nitrat, Pospat, BOD dan COD) yang diambil setiap minggu dalam waktu 3 (tiga) minggu pada 3 (tiga) stasiun, dapat dilihat pada Tabel 2.

Tabel 2. Rata-rata kualitas Air Danau Hanjalutung pada masing-masing stasiun selama

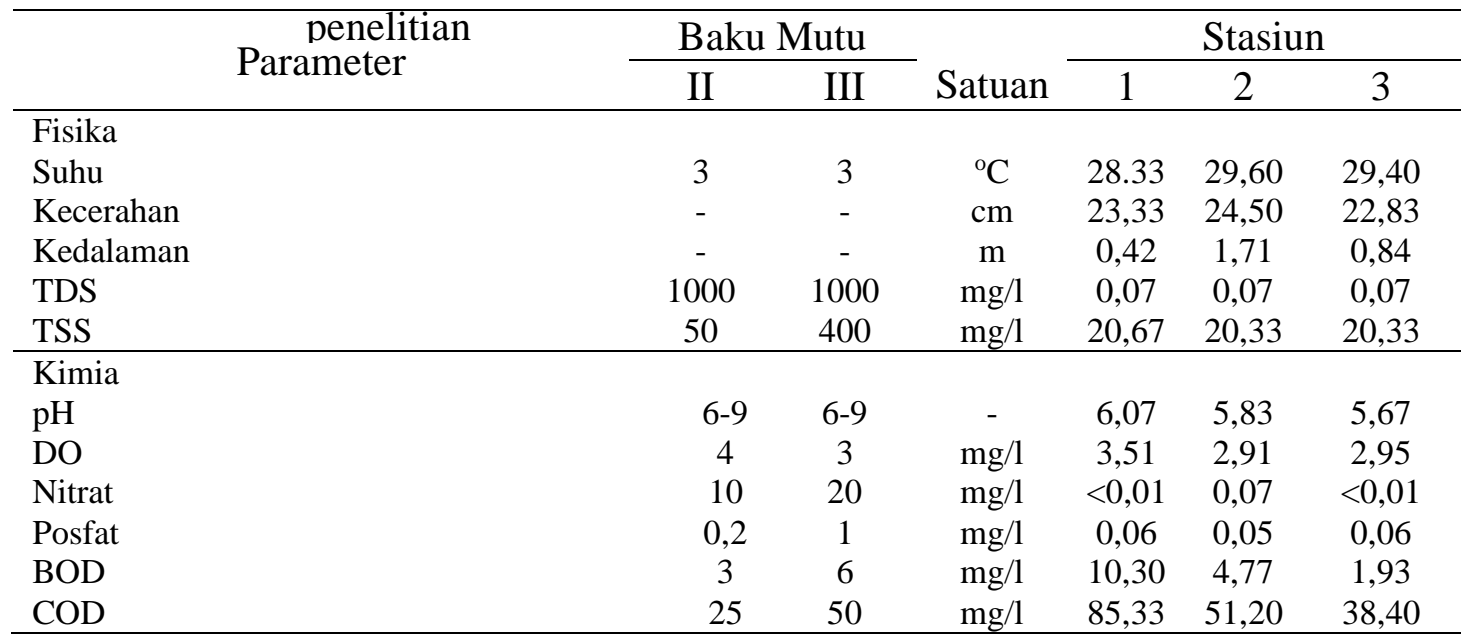




\subsection{Parameter Fisika}

a). Suhu

Suhu merupakan salah satu faktor lingkungan yang sangat berperan dalam mengendalikan ekosistem suatu perairan. Suhu air selama masa penelitian berkisar antara $28,33^{\circ} \mathrm{C}-29,40^{\circ} \mathrm{C}$ (Gambar 2). Nilai suhu air Danau Hanjalutung setiap stasiun masih sesuai dengan baku mutu air yang ditetapkan oleh pemerintah dalam PP No.82 Tahun 2001 terutama Kelas II dan III.

\section{b). Kecerahan}

Kecerahan air Danau Hanjalutung berkisar 22,83 cm - 24,50 cm (Gambar 2). Dari hasil pengukuran kecerahan selama penelitian, nilai kecerahan yang tertinggi terdapat pada stasiun 3 minggu pertama dan nilai kecerahan terendah terdapat pada stasiun 3 minggu kedua. Kecerahan perairan dipengaruhi oleh keberadaan zat-zat terlarut, partikelpartikel dan warna air. Nilai kecerahan dipengaruhi keadaan cuaca, waktu pengukuran, kekeruhan, serta ketelitian orang yang melakukan pengukuran (Ciptano, 2010).

Kecerahan adalah sebagian cahaya yang diteruskan ke dalam air dan dinyatakan dengan persen (\%), dari beberapa panjang gelombang di daerah spektrum yang terlibat cahaya yang melalui lapisan sekitar satu meter, jatuh agak lurus pada permukaan air. Kemampuan cahaya matahari untuk menembus sampai ke dasar perairan dipengaruhi oleh kekeruhan suatu perairan (Maniagasi, R. dkk., 2013). Tingginya nilai kecerahan karena berada diatas nilai kecerahan $25 \mathrm{~cm}$. Menurut Kordi dan Tancung (2005), semua plankton jadi berbahaya kalau nilai kecerahan suatu perairan kurang dari $25 \mathrm{~cm}$ kedalaman piringan secchi.

\section{c). Kedalaman}

Kedalaman air Danau Hanjalutung berkisar antara 0,42 m - 1,17 m (Gambar 2). ST 2 memiliki nilai kedalaman yang lebih besar dibandingkan Stasiun 1 dan Stasiun 3, yaitu 1,71 $\mathrm{m}$ karena Stasiun 2 merupakan bagian tengah dari danau tersebut yang memiliki cekungan yang lebih dalam. Oleh sebab itu, di sekitar Stasiun 2 terdapat bangunan terapung yang digunakan sebagai tempat melakukan kegiatan budidaya ikan lokal.

\section{d). Total Suspended Solid (TSS)}

Total Suspended Solid (TSS) merupakan material padat termasuk organik dan anorganik, yang melayang di air, dapat berupa fitoplankton, zooplankton, mikroba yang hidup dan mati, kotoran manusia dan binatang, bagian dari tanaman atau binatang yang sedang terdekomposisi dan limbah industri (Verma dan Singh, 2013; Soewandita dan Sudiana, 2010 dalam Salim, A.G., dan Dharmawan, I.W.S. 2017). Kandungan TSS berhubungan erat dengan kecerahan perairan, dan tingginya konsentrasi TSS akan menurunkan kualitas air melalui penyerapan cahaya. Perubahan secara fisika meliputi penambahan zat padat baik bahan organik mau pun anorganik ke dalam perairan sehingga meningkatkan kekeruhan yang selanjutnya akan menghambat penetrasi cahaya matahari ke badan air. Berkurangnya penetrasi cahaya matahari akan berpengaruh terhadap proses fotosintesis yang dilakukan oleh fitoplankton dan tumbuhan air lainnya (Salim, A.G., dan Dharmawan, I.W.S. 2017; Rinawati, dkk., 2016)

Nilai TSS pada masing-masing stasiun penelitian berkisar antara 20,00 mg/l-20,67 mg/l dengan rata-rata nilai TSS adalah 20,33 mg/l(Gambar 2). Jika dibandingkan dengan PP No.82 Tahun 2001 terutama Kelas II dan III, maka nilai TSS tersebut masih memenuhi satandar yang telah ditetapkan tersebut. Nilai TSS yang diperbolehkan dalam PP No.82 Tahun 2001untuk Kelas II adalah 50 mg/l dan Kelas III adalah 400 mg/l. 

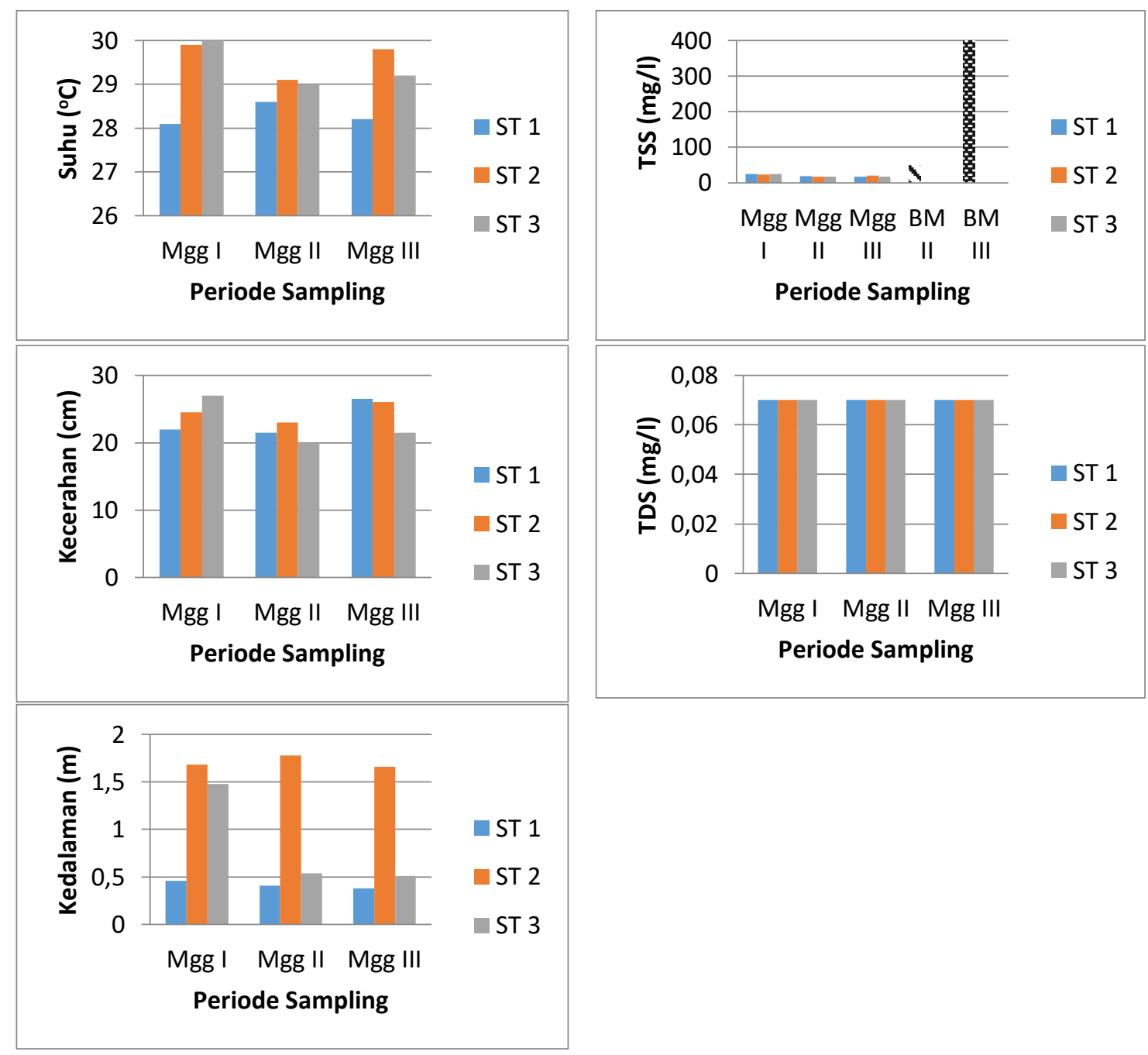

Gambar 2. Parameter Fisika: Suhu, Kecerahan, Kedalaman, TSS dan TDS

e). Total Dissolved Solid (TDS)

Total padatan terlarut (TDS) merupakan bahan-bahan padatan dapat terlarut dalam air yang terdiri dari senyawa-senyawa anorganik dan organik baik berupa air mineral dan garam-garamnya (Setiari, 2012 dalam Salim, A.G., dan Dharmawan, I.W.S. 2017 ). Bahan-bahan tersebut dapat meningkatkan nilai kekeruhan yang dapat menghambat penetrasi cahaya ke dalam perairan sehingga mempengaruhi proses fotosintesis. Nilai rata-rata TDS setiap stasiun dalam air Danau Hanjalutung adalah 0,07mg/l (Gambar 2). Nilai tersebut masih jauh lebih kecil dibandingkan dengan baku mutu yang ditetapkan oleh pemerintah yaitu $1000 \mathrm{mg} / \mathrm{l}$ untuk Kelas II dan III.

\subsection{Parameter Kimia}

a). Derajat Keasaman $(\mathrm{pH})$

Nilai derajat keasaman $(\mathrm{pH})$ air Danau Hanjalutung berkisar antara 5.67-6.07. Kecenderungan nilai $\mathrm{pH}$ pada setiap stasiun mengalami peningkatan (Gambar 3). Jika dibandingkan dengan mutu air yang ditetapkan PP No.82 Tahun 2001, maka nilai nilai $\mathrm{pH}$ air Danau Hanjalutung lebih rendah dari baku mutu yang ditetapkan baik untuk kelas II dan III. 
Boyd, C.E., 2010 dalam Supriatna, dkk (2020) menyebutkan bahwa pH menggambarkan aktivitas potensial ion hidrogen dalam larutan yang dinyatakan sebagai konsentrasi ion hidrogen $(\mathrm{mol} / \mathrm{l})$ pada suhu tertentu, atau $\mathrm{pH}=-\log (\mathrm{H}+)$. Air murni mempunyai nilai $\mathrm{pH}=7$, dan dinyatakan netral, sedang pada air payau normal berkisar antara 7-9. Konsentrasi $\mathrm{pH}$ mempengaruhi tingkat kesuburan perairan karena mempengaruhi kehidupan jasad renik. Proses penguraian bahan organik menjadi garam mineral, seperti amonia, nitrat dan fosfat yang berguna bagi fitoplankton dan tumbuhan air lebih cepat terjadi jika kisaran pH berada pada kisaran basa (Supriatna, dkk., 2020)

$\mathrm{pH}$ yang ideal bagi kehidupan biota air tawar adalah antara $6,8-8,5 \mathrm{pH}$ yang sangat rendah, menyebabkan kelarutan logam-logam dalam air makin besar, yang bersifat toksik bagi organisme air, sebaliknya $\mathrm{pH}$ yang tinggi dapat meningkatkan konsentrasi amoniak dalam air yang juga bersifat toksik bagi organisme air (Tatangindatu, dkk,2011)

\section{b). Dissolved Oxygen (DO)}

Dissolved Oxygen (DO) yang rendah diikuti dengan kondisi perairan dan perubahan warna air. Oksigen memegang peranan penting sebagai indikator kualitas perairan, karena oksigen terlarut berperan dalam proses oksidasi dan reduksi bahan organik dan anorganik. Selain itu, oksigen juga menentukan aktivitas biologis yang dilakukan oleh organisme aerobik atau anaerobik. Dalam kondisi aerobik, peranan oksigen adalah untuk mengoksidasi bahan organik dan anorganik dengan hasil akhirnya adalah nutrien yang pada akhirnya dapat memberikan kesuburan perairan. Dalam kondisi anaerobik, oksigen yang dihasilkan akan mereduksi senyawa- senyawa kimia menjadi lebih sederhana dalam bentuk nutrien dan gas (Salmin, 2005). Sumber utama oksigen terlarut dalam air adalah difusi dari udara dan hasil fotosintesis organisme yang mempunyai klorofil yang hidup di perairan (Christina, 2014). Semakin tinggi kandungan oksigen terlarut (DO) semakin bagus kualitas air tersebut (Simanjutak, 2007).

Kandungan oksigen terlarut (DO) setiap stasiun berkisar antara 2,91 mg/l-3,51 mg/l (Gambar 3). Nilai kisaran DO pada Stasiun 1 yaitu 3,3 mg/l-3,62 mg/l dan Stasiun 2 berkisar antara 2,4 mg/l - 3,5 mg/l sedangkan pada Stasiun 3 berkisar antara 2,71 mg/l 3,23mg/l. Berdasarkan PP No.82 Tahun 2001, kandungan DO Danau Hanjalutung masih masuk dalam baku mutu yang ditetapkan baik untuk kelas II maupun kelas III.

\section{c). Biochemical Oxygen Demand (BOD)}

Biochemical Oxygen Demand (BOD) menunjukkan jumlah oksigen yang diperlukan oleh bakteri dan mikroorganisme lainnya pada saat mendekomposisi bahan organik dalam konsidi aerobik. BOD adalah sebuah ukuran jumlah oksigen yang dibutuhkan untuk menghilangkan limbah bahan organik dari perairan dalam proses dekomposisi oleh bakteri aerobik (USGS, 2021).

Konsentrasi BOD air Danau Hanjalutung berkisar antara 1,93 mg/l - 10,30 mg/l. Secara berturut-turut, konsentrasi BOD setiap stasiun adalah 10,30 mg/l (Stasiun 1), 4,77 mg/l (Stasiun 2), dan 1,93 mg/l (Stasiun 3) (Gambar 3).

Berdasarkan PP No.82 Tahun 2001, konsentrasi BOD di Danau Hanjalutung melebihi ambang batas yang ditetapkan oleh pemerintah. Konsentrasi BOD untuk Kelas II dan Kelas III yang diperbolehkan adalah $3 \mathrm{mg} / \mathrm{l}$ dan $6 \mathrm{mg} / \mathrm{l}$. Tingginya nilai BOD diduga karena adanya kegiatan budidaya ikan yang dilakukan di danau tersebut sehingga kandungan bahan organiknya tinggi, maka oksigen yang diperlukan untuk merombak 
bahan organik tersebut juga tinggi. Hal ini juga sesuai dengan hasil penelitian Tatangindatu, dkk (2011) menyatakan bahwa tingginya BOD disebabkan tingginya bahan organik terutama sisa pakan dari peternakan itik yang aada di Danau Tondano.

\section{d). Chemical Oxygen Demand (COD)}

Chemical Oxygen Demand (COD) adalah jumlah oksigen yang dibutuhkan untuk mengoksidasi zat-zat organik yang terdapat dalam limbah cair dengan nilai COD merupakan ukuran bagi pencemaran air oleh zat organik yang secara alamiah dapat dioksidasi melalui proses biologis dan dapat menyebabkan berkurangnya oksigen terlarut dalam air (Indonesian Public Health, 2015)

Kisaran nilai COD Danau Hanjalutung yaitu berkisar antara 38,40 mg/l-85,33 mg/l (Gambar 3). Nilai tersebut lebih tinggi dibandingkan dengan PP No.82 Tahun 2001 untuk Kelas II $(25 \mathrm{mg} / \mathrm{l})$ dan Kelas III $(50 \mathrm{mg} / \mathrm{l})$. Tingginya nilai COD di Danau Hanjalutung kemungkinan dipengaruhi oleh adanya kegiatan budidaya ikan, sehingga bahan organik dalam perairan meningkat. Pemberian pakan yang berlebihan di dalam perairan diduga menjadi faktor nilai COD yang tinggi. COD memiliki arti kebutuhan oksigen untuk reaksi oksidasi secara kimia terhadap bahan pencemar di dalam air. Tingginya kebutuhan oksigen yang dibutuhkan oleh reaksi oksidasi terhadap bahan pencemar di dalam air akan mempengaruhi kadar oksigen yang tersedia di dalam perairan. Di sisi lain, oksigen juga dibutuhkan oleh makhluk hidup yang berada di dalam perairan. Hal ini berdampak pada ketersedian DO di dalam air yang tidak sesuai dengan kebutuhan COD yang dibutuhkan untuk menguraikan bahan- bahan pencemar. Akibatnya, bahan-bahan pencemar di dalam air tidak dapat diproses dengan optimal. Nilai COD meningkat seiring dengan meningkatnya kandungan bahan organik dalam perairan (Boyd dalam Yusuf \& Handoyo, 2004). Berdasarkan hasil penelitian Hamakonda, dkk (2019), kandungan organik dalam perairan menyebabkan tingginya kandungan COD di dalam perairan.

\section{e). Nitrat}

Namun hal ini tentunya harus mendapatkan perhatian karena kadar nitrat yang lebih dari $0.2 \mathrm{mg} / \mathrm{L}$ dapat menyebabkan terjadinya eutrofikasi perairan, dan selanjutnya dapat menyebabkan blooming sekaligus merupakan faktor pemicu bagi pesatnya pertumbuhan tumbuhan air seperti eceng gondok. Nitrat (NO3 ) adalah bentuk utama nitrogen di perairan alami dan merupakan sumber nutrisi utama bagi pertumbuhan fitoplankton dan tumbuhan air lainnya. Kadar nitrat yang lebih dari $5 \mathrm{mg} / \mathrm{L}$ menggambarkan telah terjadinya pencemaran (Tatangindatu, dkk , 2011)

Nilai rata-rata nitrat $\left(\mathrm{NO}_{3}\right.$ ) pada perairan Danau Hanjalutung berkisar antara $0,01 \mathrm{mg} / \mathrm{l}$ - 0,07 mg/l (Gambar 3). Berdasarkan PP No.82 Tahun 2001, kadar nitrat pada setiap stasiun masih dibawah baku mutu yang telah ditetapkan.

Wetzel, R.G. (1975) dalam Mustofa, A (2015) mengklasifikasi kriteria kesuburan perairan berdasarkan kandungan Nitrat. Kandungan Nitrat kurang dari 0,23 termasuk perairan kurang subur; Kandungan Nitrat antara $0,23 \mathrm{mg} / \mathrm{l}-1,13 \mathrm{mg} / \mathrm{l}$ termasuk perrairan dengan kesuburan sedang; dan kandungan Nitrat antara 1,13-11,29 mg/l termasuk perairan dengan kesuburan tinggi. Berdasarkan kriteria tersebut maka Danau Hanjalutung tergolong kedalam perairan kurang subur (kandungan Nitrat kurang dari $0,23 \mathrm{mg} / \mathrm{l})$

f). Posfat

Posfat merupakan salah satu zat hara yang dibutuhkan dan mempunyai pengaruh terhadap pertumbuhan dan perkembangan hidup organisme perairan. Tinggi rendahnya 
kadar fosfat dan nitrat di suatu perairan adalah salah satu indikator untuk menentukan kesuburan perairan (Patty, 2014 dalam Darmawan, A., dkk.. 2018 ).
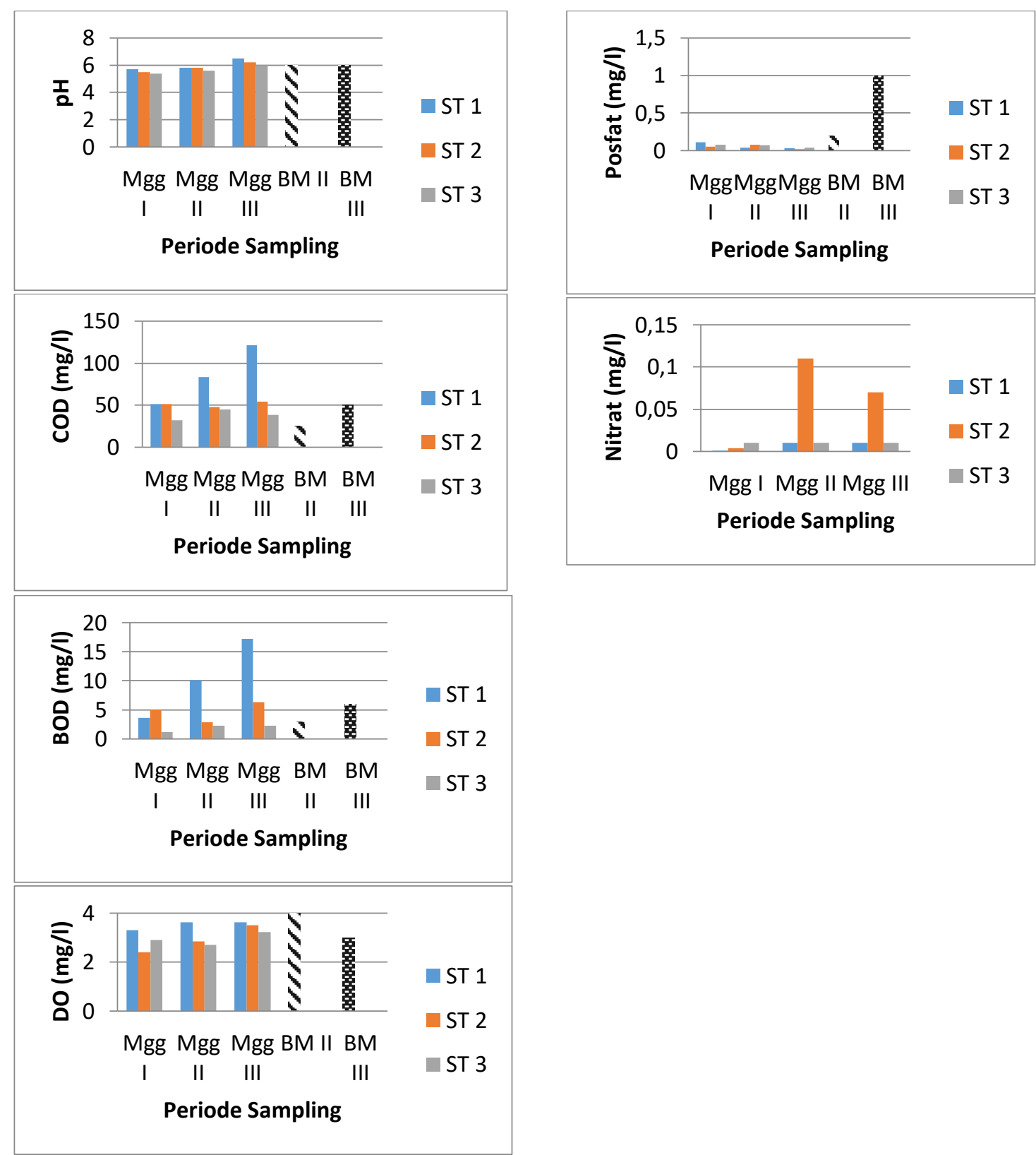

Gambar 3. Parameter Kimia: pH, DO,BOD, COD, Nitrat dan Posfat

Nilai posfat pada Stasiun 1 pada minggu pertama mempunyai nilai yang lebih tinggi dibandingkan dengan Stasiun 1 minggu kedua yaitu $0,04 \mathrm{mg} / \mathrm{l}$ dan pada Stasiun 1 minggu ketiga 0,03 mg/l. Kisaran nilai fosfat di Danau Hanjalutung adalah 0,05 mg/l $0,006 \mathrm{mg} / \mathrm{l}$ (Gambar 3). Menurut Vollenweider dalam Effendi (2003), klasifikasi status tropik fosfat di perairan terdiri dari 3 kriteria yaitu kadar fosfat berkisar antara 0.003 $\mathrm{mg} / \mathrm{l}$ hingga $0.01 \mathrm{mg} / \mathrm{l}$ untuk perairan oligotropik; kadar fosfat $0,011 \mathrm{mg} / \mathrm{l} \mathrm{hingga} 0,03$ $\mathrm{mg} / \mathrm{l}$ untuk perairan mesotrofik; dan kadar fosfat $0,031 \mathrm{mg} / 1$ hingga $0,1 \mathrm{mg} / \mathrm{l}$ untuk perairan eutrofik.

Berdasarkan baku mutu PP No.82 Tahun 2001 (Kelas II dan III), kadar posfat $\left(\mathrm{PO}_{4}\right)$ di Danau Hanjalutung masih dibawah nilai yang ditetapkan yaitu $0,2 \mathrm{mg} / \mathrm{l}$ untuk Kelas II 
dan $1 \mathrm{mg} / \mathrm{l}$ untuk Kelas III. Jika melihat dari kriteria kesuburan perairan tersebut diatas, maka Danau Hanjalutung merupakan perairan dengan tingkat kesuburan tinggi (eutrofik) karena memiliki nilai fosfat yang berada antara $0,031 \mathrm{mg} / \mathrm{l}$ hingga $0,1 \mathrm{mg} / \mathrm{l}$.

\section{KESIMPULAN}

1. Secara fisika dan kimia, kualitas air Danau Hanjalutung masih memenuhi baku mutu yang ditetapkan oleh pemerintah dalam PP No.82 Tahun 2001.

2. Beberapa parameter kualitas air seperti BOD dan COD memiliki nilai yang telah melebihi baku mutu yang ditetapkan dalam PP No.82 Tahun 2001

\section{DAFTAR PUSTAKA}

Augusta, T.S . 2013. Struktur Komunitas Zooplankton Di Danau Hanjalutung Berdasarkan Jenis Tutupan Vegetasi Zooplankton. Jurnal Ilmu Hewani Tropika Vol 2. No. 2. Desember 2013, Hal: 68-74

Augusta, T. S dan Evi, S.U. 2014. Analisis Hubungan Kualitas Air Terhadap Komunitas Zooplankton dan Ikan di Danau Hanjalutung. Jurnal Ilmu Hewani Tropika Vol 3. No. 2.

Augusta, T. S. 2015. Inventarisasi Ikan dan Kondisi Habitat di Danau Hanjalutung Kalimantan Tengah. Jurnal Ilmu Hewani Tropika Vol 4. No. 2. Desember 2015

Asdak, (1995). Hidrologi dan Pengelolaan DAS. Gadjah Mada University Press. Yogyakarta.

Badan Penelitian Daerah (BAPPEDA) Palangkaraya. (2016). Laporan Akhir Kegiatan Masterplan Kawasan Minapolitan Di Palangkaraya.

Christina, M. Yusuf, M., Maslukah,L. 2014. Sebaran Kualitas Perairan Ditinjau Dari Zat Hara, Oksigen Terlarut Dan pH Di Perairan Selat Bali Bagian Selatan. Jurnal Oseanografi. 3 (2): 142- 150.

Ciptanto, S. (2010). Top 10 Ikan Air Tawar. Lily Publisher. Yogyakarta.

Darmawan, A., Sulardiono, B., Haeruddin. 2018. Analisis Kesuburan Perairan Berdasarkan Kelimpahan Fitoplankton, Nitrat Dan Fosfat Di Perairan Sungai Bengawan Solo Kota Surakarta. Journal of Maquares. Volume7, Nomor 1, Tahun 2018, Hal: 1-8

Daryanto (1995). Masalah Pencemaran. Bandung: Penerbit Tarsito.

Dinas Kelautan dan Perikanan (DKP). (2011). Laporan Tahunan 2010. Dinas Kelautan dan Perikanan Provinsi Kalimantan Tengah. Palangka Raya.

Effendi, H. 2003. Telaah Kualitas Air bagi Pengelolaan Sumber Daya Lingkungan Perairan. Kanisius. Yogyakarta. 243 p

Hamakonda, U.A, Suharto, B, Susanawati, L.D.. 2019. Analisis Kualitas Air Dan Beban Pencemaran Air Pada Sub Das Boentuka Kabupaten Timor Tengah Selatan. Jurnal Teknologi Pertanian Andalas Vol. 23, No.1, Maret 2019: 56-67.

Hariyadi, S., Suryadiputra , I.N.N, dan Widigdo B. (1992). Limnologi Metode Kualitas Air. Edisi I. Fakultas Perikanan IPB. Bogor. 
Indonesian Public Helath. 2015. http://www.indonesianpublichealth.com/pengertian-bod-cod-tss-pada-air-limbah/\#

Maniagasi, R. Tumembouw, R.S., Mundeng, Y. 2013. Analisis kualitas fisika kimia air di areal budidaya ikan Danau Tondano Provinsi Sulawesi Utara. Budidaya Perairan.. Vol. 1 No. 2: 29-37. Mei 2013.

Muhammad. (1995). Ekologi perikanan DAS. Bogor. Fakultas Pertania IPB.

Mustofa, A. 2015. Kandungan Nitrat Dan Pospat Sebagai Faktor Tingkat Kesuburan Perairan Pantai. Jurnal DISPROTEK Volume 6: 1

Presiden Republik Indonesia. (2001). Peraturan Pemerintah Republik Indonesia Nomor 82 Tahun 2001. Tentang Pengelohan Kualitas Air dan Pengendalian Pencemaran Air. Sekretaris Negara Republik Indonesia. Jakarta. 28 hal.

Tatangindatu, F, Kalesaran, O. Rompas, R. 2011. Stusi Parameter Fisika Kimia Air pada Areal Budidaya Ikan di Danau Tondono desa Paleloan. Minahasa: Budidaya Perairan. Sulawesi Utara.

Rinawati, Hidayat, D , R. Suprianto , Dewi, P.S. 2016. Penentuan Kandungan Zat Padat (Total Dissolve Solid Dan Total Suspended Solid) Di Perairan Teluk Lampung, Analit: Analytical And Environmental Chemistry, Volume 1, No 01, Oktober 2016.

Salim, A.G dan Dharmawan, I.W.S. 2017. Analisis Kualitas Air Sungai di DAS Citarum Bagian Hulu. Bunga Rampai Pengelolaan Lahan dan Air Berkelanjutan dengan Melibatkan Masyarakat.. Editor . Mulyanto, B., Dharmawan, I.W.S., Forda Press, Bogor 2017. Hal. 49-62

Salmin. 2005. Oksigen Terlarut (DO) dan Kebutuhan Oksigen Biologi (BOD) Sebagai Salah Satu Indikator Untuk Menentukan Kualitas Perairan. Oseana. XXX (3): 21-26. (Online), (http://oseanografi.lipi.go.id/dok umen/oseana_xxx(3)21-26.pdf, diakses 15 Mei 2017).

Simanjutak, M. (2007). Oksigen Terlarut dan Apparent Oxygen Utilization di Perairan Teluk Klabat Pulau Bangka. Jurnal Ilmu Kelautan. 12 (2): 59-66.

Supriatna , Mahmudi, M , Musa, M , Kusriani. 2009. Hubungan pH Dengan Parameter Kualitas Air Pada Tambak Intensif Udang Vannamei (Litopenaeus Vannamei) Journal Of Fisheries And Marine Reseach. Vol 4 No 3: 368-374

Suraya, U. 2019. Inventarisasi Dan Identifikasi Tumbuhan Air Di Danau Hanjalutung Kota Palangka Raya. Daun: Jurnal Ilmiah Pertanian Dan Kehutanan. Volume 6 No 2.

Susila, N. 2012. Analisis Sosial Ekonomi Masyarakat Kelurahan Petuk Katimpun Dalam Mendukung Pemanfaatan Danau Hanjalutung Sebagai Kawasan Alternatif Pengembangan Usaha Perikanan Di Kota Palangka Raya. Jurnal Ilmu Hewani Tropika (Journal Of Tropical Animal Science). Vol 1, No 2 (2012) 
Akhdiana, I, Haryani, G.S., Dina, R., Lukman, Samir, O., Husni, S. 2017. Iktiofauna Danau Hanjalutung, Kalimantan Tengah. Prosiding Pertemuan Ilmiah Masyarakat Limnologi Indonesia Tahun 2017, 2018,403

USGS. 2021. Biological Oxygen Demand (BOD) and Water https://www.usgs.gov/special-topic/water-science-school/science/biological-oxygendemand-bod-and-water?qt-science_center_objects=0\#qt-science_center_objects (diakses tanggal 25 Maret 2021)

Yusuf, M dan Handoyo, G. 2004. Dampak Pencemaran Terhadap Kualitas Perairan dan Strategi Adaptasi Organisme Makrobenthos di Perairan Pulau Tirangcawang Semarang. Indonesian Journal of Marine Sciences.Vol. 9 (1), Maret 2004: 12- 42 